\title{
Put not your faith in princes (or courts) - agreements made from asymmetrical power bases: the story of a promise made to Western Australia's Aboriginal people
}

\author{
Steven Churches
}

\begin{abstract}
The conquest of the earth, which mostly means the taking it away from
those who have a different complexion or slightly flatter noses than ourselves, is not a pretty thing when you look into it too much. What redeems it is the idea only. An idea at the back of it; not a sentimental pretence but an idea; and an unselfish belief in the idea - something you can set up, and bow down before, and offer a sacrifice to ... ${ }^{1}$
\end{abstract}

\section{Introduction}

My paper is written from recent personal experience, and though there is dissatisfaction in my reflections on that experience, I should not want to detract from the utility of other papers in this volume. The story that I tell is merely cautionary of the perils of agreements reached where the parties involved have widely different power bases. Which is not to say that agreements or treaties will only ever hold between those who are equals in numbers or wealth.

When I contemplate the success (certainly in recent years) of the Treaty of Waitangi in New Zealand, I am confronted with an acceptance which is iconic. Certainly some Pakeha (Europeans) complain about the contemporary working out of the Treaty, but, operating at a level way above such a mentality, is the assurance which New Zealanders feel in having this agreement as the very foundation upon which the nation is built. An attempt was made at a first formal engagement to regularise the relationship of the Maori and the newcomers who were intent on settling among them.

The Indigenous peoples of Australia had no such foundation document recognising the difficulties in the meeting of two different cultures: the early Governors' proclamations of equality of all before the law were well meaning but, of course, unilateral in their expression and application. It would be the law of the newcomers which would be applied equally.

Alone in Australia, the Aboriginal people of the western third were recognised in a foundation document, the Constitution of Western Australia, which came into force in 1890. That document provided in section 70 that $1 \%$ of public revenue should be paid to a Board (not under local political control) for the welfare of Indigenous people. The first lesson to be learnt is one of the need for acceptance: as the colonists publicly said from the time they opened their new Parliament in 1890, this provision was forced on them by the Imperial Government as the 
price for self-government. The ' $1 \%$ clause' was widely hated, and the colonists set out to repeal it at the earliest opportunity.

The story in this paper is that of the fight over the existence of s.70: a sprawling fight over a century between bureaucrats and statesmen in London and politicians in Perth, do-gooders and lawyers, and the matter was finally brought to legal resolution in 2001 in the High Court decision Yougarla $v$ WA. ${ }^{2}$ The High Court pronounced the section dead, and my decade and longer involvement as counsel for Crow Yougarla, and before him, Snowy Judamia, came to an end.

\section{The well-spring of generosity to Indigenous peoples}

The last successful military field campaigns waged by Indigenous peoples against colonising forces in the nineteenth century ${ }^{3}$ were the engagements at the Little Big Horn in late June 1876, and at Isandlwana two and a half years later in January 1879: 200 killed by the Sioux at the first, and 800 redcoats dead by Zulu hand at the latter. But the tide was about to change irrevocably with the industrialisation of the means for making war. As Hilaire Belloc wrote (a fair summary of Rhodes's advance into Mashonaland in the 1890s):

Whatever happens, we have got

The Maxim Gun, and they have not. ${ }^{4}$

The 1880s saw a burst of official philanthropy in favour of the Indigenous peoples (presumably on the basis that magnanimity to a conquered foe is the best policy). ${ }^{5}$ The US Congress enacted the Dawes Act in 1887, which provided for the tribal land of the Blackfeet Indians to be taken from them, to be sold in small allotments, but the proceeds of the sales to be held on trust for the tribe. A Blackfeet accountant, Eloise Cobell, looked into the amounts unpaid by the Federal Government into this trust, and discovered that the total was now running in the order of \$US10 billion. She is well ahead so far, having her case against former Clinton Cabinet Secretary for the Interior Norton upheld (at least as to preliminary procedural matters) by the Federal Court of Appeals. ${ }^{6}$ Along the way, two former Clinton Cabinet members have been cited for contempt for failing to produce the documents required by the Court. $^{7}$

In 1889 the Tasmanian Parliament passed an Act (No. 67 of 1889) authorising a grant of 300 acres of land 'to Fanny Smith, an Aboriginal'. Truganini had died in 1876: Cassandra Pybus in Community of Thieves ${ }^{8}$ makes a strong case for Fanny Cochrane Smith being the last full blood Tasmanian Aborigine, and Fanny's story is a happy one of a woman who was self-assured, ran a boarding house in Hobart, and raised eleven children with her husband, James Smith. This personal history rises above the fate of the agreement the Tasmanian Aboriginal people

\footnotetext{
2 (2001) 207 CLR 344.

3 The exploits of Jandamarra (Pigeon) in the West Kimberley in the 1890 amounted to guerrilla warfare: see Pedersen 1995.

${ }^{4} \mathrm{http}: / /$ www.nationmaster.com/encyclopedia/Maximmachine-gun

${ }^{5}$ Motive is, of course, more complex than this comment allows, and a sense of genuine philanthropy flavours much of the intention in drafting 5.70 , to be discussed below.

${ }^{6}$ Cobell v Norton (2001) 240 F 3d 1081 (US CA, D of Col Circt). A computer search in June 2004 reveals much procedural skirmishing since 2001, much of it with the appearance of delay by Government.
}

\footnotetext{
${ }^{7}$ The Ilois people of the Chagos Archipelago in the Indian Ocean did well in litigation at the same time: the English Court of Appeal held that the British Government had not had prerogative power in the period 1965-1971 to push these people off their islands to make way for the US airbase at Diego Garcia: $R$ (Bancoult) $v$ Secretary of State for Foreign and Commonwealth Affairs [2001]. The reflections of the appeal judges on the senior bureaucrats only a generation earlier could provide a script for 'Yes Prime Minister', and indeed the archipelago has already provided the material for one show in the series, 'A Victory for Democracy'. The English High Court failed to deliver a win to the llois at the next round, the successful attempt at strike out by the Government: Chagos Islanders v The Attorney General, Her Majesty's British Indian Ocean Territory Commissioner [2003] (Ouseley J) (the subject of appeal at time of writing).

8 Pybus 1991.
} 
entered into with the colonial authorities, to vacate mainland Tasmania in exchange for free life on Flinders Island, which agreement was the subject of a petition to Queen Victoria in 1846, to no great effect. ${ }^{9}$

But would any of this generosity of spirit extend to the Indigenous people of Western Australia?

\section{The reported condition of the Indigenous people of WA in the 1880s and its impact at the highest level}

The claims made in the period $1885-1886$ by the Rev John Gribble against the settlers in the northern half of WA for what he saw as their monstrous treatment of the Indigenous people are well known, as is his loss of a defamation suit against The West Australian newspaper in 1887 after it had referred to him 'as a lying, canting humbug'. What is less well known in WA is that the then Governor, Sir F Napier Broome, had been receiving contemporaneous reports from two senior government officials, operating independently of each other, confirming Gribble's assertions of depravity and de facto slavery. In April 1886, Lt Col EF Angelo, the Government Resident at Roebourne, wrote to Broome referring to a 'disguised but unquestionable system of slavery carried on under the protection of the British flag' in Roebourne. He named two residents who advertised themselves as able to 'put niggers aboard [pearling boats] at half a Crown apiece'. The local Justices of the Peace who sat on the Bench in Petty Sessions had their own pearling interests, and did nothing about this behaviour. ${ }^{10}$ Broome sent a Fremantle Magistrate, Fairbairn, to report on what was going on in the north: his report of February 1887 corroborated that of Angelo. Broome suppressed this information, which never found its way to Gribble's defamation trial. ${ }^{11}$

But Broome cannot have been unaffected by what he had read in the years 1886-1887: in the context of the growing push for responsible self-government in WA in the late 1880s, Broome began a correspondence with the British Secretary of State for the Colonies, Sir Henry Holland (later Lord Knutsford), referring particularly to the needs of the Indigenous people under a colonial constitution in WA. Broome first wrote to Holland on the subject on 12 July 1887 after the Legislative Council had resolved for responsible government. The Governor suggested that there be a Board independent of local political control, and that $£ 5000$ per annum be expended by the Board for the benefit of the native population. He concluded delphically:

Legislation affecting the Natives could, of course, be carefully considered by the Governor and, when necessary, by Her Majesty's

Government, under the ordinary constitutional procedure. ${ }^{12}$

A letter from Broome of 28 May 1888 to Lord Knutsford (as Holland had now become) again set out Broome's proposals on the subject: there should be an independent Board seeing to the welfare of the natives, and $£ 5000$, or $1 \%$ of public revenue when the Colony's revenue exceeded $£ 500,000$ (which it was to do after the discovery of gold in 1893) should be payable to that Board to finance its functions. ${ }^{13}$ Broome recorded the hostility of the Legislative Council to the plan for an independent Board, an antagonism which the politicians of WA never dropped, although it was concealed when necessary.

\footnotetext{
9 Reynolds 1995.

${ }^{10}$ Pullan 1984: 130.

${ }^{11}$ The miserable treatment by both colonial and imperial authorities

of men like Gribble and Angelo is recorded in Reynolds 1998.
}

\footnotetext{
${ }^{12}$ British Parliamentary Papers: Colonies Australia (hereafter BPP) vol 31: 358.

${ }^{13}$ BPP vol 31: 380-2, paras 21-4. All documents referred to from this point, including this one, were before the courts in the litigation described later in the chapter.
} 
With this letter was enclosed a draft Bill for a Constitution for WA, which discloses that Broome was alert to the necessity of entrenching a proposal such as he had just floated: since the attitude of the colonists was predictably adverse, the measure would have to be protected against easy repeal by the new colonial Parliament, the establishment of which was the main object of the pressure for responsible government.

\section{The proposed protection of the $1 \%$ measure}

In the Bill forwarded by Broome, the $1 \%$ provision first surfaces as clause 52 . The entrenching of the constitutional arrangements for the colonial Parliament was set out in clause 57, and included tabling of any proposed Bill for change in both Houses of the Imperial Parliament for 30 days prior to any Royal Assent. Clause 52 was not made directly the subject of such restraint in this draft, but Broome suggested that alteration of that provision should be in accordance with the tabling procedure in clause $57 .{ }^{14}$

The idea of tabling colonial laws and amendments had first arisen in the period 1823-1828 in relation to NSW and Van Diemen's Land (Tasmania), when both colonies were little more than military despotisms. ${ }^{15}$ The first relevant raising of tabling for colonial constitutional amendments occurred in the Imperial Act of 1850, the Australian Colonies Constitutions Act (No 2). Section 32 of that Act provided that amendments to the constitution of the legislatures of the colonies would require tabling at Westminster. They would also require the cautionary treatment set out in the Australian Colonies Constitution Act (No 1) of 1842, which provided that legislation impacting on the election to or the constitution of a legislature had to make the journey to London for Royal Assent and back to the colony within two years (lest it become politically stale) and that, on its return, it had to be proclaimed publicly to ensure that the citizenry understood the existence of this new law, which had been given life offshore.

Knutsford sent a revised version of the Constitution back to Broome on 31 August 1888, with the $1 \%$ provision now being clause 58 , and the entrenching provision (clause 61) now merely requiring reservation 'for Her Majesty's pleasure'. The $1 \%$ was still not entrenched, and the requirements involved in the overview by the imperial authorities were now more obscure. ${ }^{16}$ The Bill for the Constitution now started to move through the existing WA Legislative Council. Broome reported to Knutsford on 1 April 1889 that, acting on Knutsford's instructions of 15 March 1889 (which are no longer available), clause 73 now provided for certain provisions in the Constitution to be reserved if being altered. ${ }^{17}$

On 29 April 1889 Broome was able to send the Bill, in the final form passed by the WA Parliament, to Knutsford. The 1\% provision was now clause (and upon assent, section) 70, and the provision requiring reservation of certain matters if they were the subject of colonial legislation, including s.70, was to be s.73. That section merely specified that those sections set out in s.73 would require reservation. Nothing more was said in the Bill for the Constitution on the content of what was required by reservation.

The colonists sent a delegation to London in April 1890 to persuade the Imperial Parliament to the idea of responsible government for WA. Sir TC Campbell was asked by a member of the Select Parliamentary Committee what he thought of the measures in the Bill regarding Aboriginal people, to which he replied:

\footnotetext{
14 BPP vol 31: 382, para 24, and for the Bill: 393-5.

${ }^{15}$ Noted by the majority in the High Court in Yougarla 207 CLR at $357-8$ [28], but not raised in argument: fn 48 .

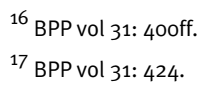

${ }^{16}$ BPP vol 31: $400 \mathrm{ff}$.

${ }^{17}$ BPP vol 31: 424 . 
I do not think that they are of any use. I think they will relieve the Colonial Government from a sense of responsibility ... [which] is a pity, but at the same time they will prevent the settlers being persecuted by what I may call the Exeter Hall factions. ${ }^{18}$

The Constitution was brought to enactment later in 1890 not merely by Royal Assent (following tabling) and subsequent proclamation, which would have been possible under the 1842 and 1850 Acts, but rather the Imperial Parliament passed the Western Australian Constitution Act 1890, to which the Bill for the Constitution was appended as a schedule. The important factor in the Imperial covering Act was that in s.2 it provided that, while the provisions of the 1842 and 1850 Acts which were repugnant to the Constitution should be repealed, such of those provisions which relate to ... the reservation of Bills ... shall apply to Bills to be passed by ...' the bi-cameral legislature to be set up under the Constitution. As noted above, the provisions of the 1842 Act (ss.31 and 33) and the 1850 Act (s.32) relating to reservation requirements did so by enumerating aspects of the election and composition of the legislature that would attract the supervisory power of the Imperial authorities by way of reservation.

The question that would arise was what, if any, of these reservation requirements applied through the link of s. 2 of the covering Act in the event that $s .70$ was the subject of legislative alteration. There was a fair argument that the matters directly referred to in the 1842 and 1850 Act reservation provisions had in fact evaporated with the 1890 covering Act, and that the only work left for $s .2$ was to connect the matters set out in s. 73 of the new Constitution, including s.70, to the requirements of the 1842 and 1850 Acts.

\section{The first legislative attack on $\mathbf{s . 7 0}$}

Broome's correspondence had correctly stated the level of hostility to both an independent Aborigines Protection Board and the provision that $1 \%$ of public revenue be paid to it. Premier John Forrest lost no time making his views known. Of the Board he wrote to new Governor Robinson in 1892:

... its existence is a grave reflection on the honour and integrity of the people of the Colony to do what is just and right to the aboriginal population, [and the feeling] is unanimous throughout the colony and we shall never be satisfied until this unjust stigma [of s.70] is removed. ${ }^{19}$

The flavour of debate in the nascent WA Parliament on the subject of the Indigenous people ranged from indignation at the Imperial imposition of the 1\% measure, apparently as the price for responsible government, to Alexander Forrest's more robust enquiries: how many Black lives measured up to the life of one Whitesettler? Forrest, whose statue graces the street corner outside the WA Supreme Court, gave an entirely new meaning to the concept 'disperse', as in 'dispersing the natives'. The Anglican Bishop of Perth, the Rt Rev COL Riley wrote to Governor Smith in July 1896 saying:

The expression 'Dispersing the natives', should be clearly defined so that we may understand what it means. ${ }^{20}$

\footnotetext{
${ }^{18}$ BPP vol 32: 119. On this page and the next appear a further five references from Sir TC Campbell regarding the 'baneful influence' of Exeter Hall, which had apparently caused the WA pearling industry to be regulated out of local control. Exeter Hall opened at 372 The Strand, London in 1831, and became a centre for British philanthropy, the Anti-Slavery World Convention being
}

held there in 1840 . Its name became associated with Britishbased opponents of slavery and those who were concerned for the welfare of Indigenous peoples under pressure from colonists throughout the Empire.

${ }^{19}$ Quoted in Reynolds 1998: 175.

${ }^{20}$ BPP vol 34: 517. 
The Bishop was in turn attacked in the colonial Parliament for spreading '.. the kind of yarn served up at Exeter Hall for the delectation of the old women - some of them wearing petticoats, and some wearing breeches'. ${ }^{21}$

In 1894 the first attempt to despatch s.70 was passed in Bill form in the WA Parliament, and sent to London as a reserved Bill. There it languished, although the WA Parliament followed it up with a memorandum to the new Secretary of State for the Colonies, Joseph Chamberlain, in October 1895, asking that assent be attended to.

Chamberlain wrote back in December 1895 to Governor Smith that without further directions from the Imperial Parliament I should not be justified in advising Her Majesty to assent to a measure which would sweep away entirely the reservation which it made on behalf of the natives at so recent a date'. ${ }^{22}$ By August 1896 Chamberlain was writing to Smith, tacitly conceding that he would organise the assent, but would first have to 'lay the correspondence before the Parliament with a view to ascertaining the general feeling of the House of Commons on the subject'. ${ }^{23}$

And he did just that, the following February of 1897, when the attention of the entire Parliament was riveted by the Committee of investigation into the Jameson Raid of 1896, the occasion on which a party of settlers from the Cape Province had attempted to overturn the Government of the Transvaal Republic by force. There seemed little doubt as to the involvement of the Cape Premier, Cecil Rhodes, but the question of the day was how far Chamberlain had been implicated in planning and foreknowledge. Despite rising concern over 50 missing telegrams between Chamberlain and Rhodes, Chamberlain sat as one of the members of the Parliamentary Committee of Inquiry.

Though Chamberlain was obviously crumbling in the course of 1896 in his support for $\mathrm{s.70}$ (a turnaround in eight months), Premier Forrest claimed the credit for persuading Chamberlain to this point of view. Forrest told the WA Legislative Assembly that while he had been in the United Kingdom earlier in 1897 attending the Queen's Diamond Jubilee, he had talked to Chamberlain, ' $\ldots$ and I do not think I was with him half-an-hour before he decided that the colony should have complete control over the aborigines ... '. ${ }^{24}$ Forrest explained Chamberlain's dilatoriness in attending to assent as the result of opposition from within the Colonial Office.

Needless to say, no one noticed the material tabled by Chamberlain regarding $5.70^{25}$ in February 1897 while he was defying the precepts of natural justice and sitting on the Committee investigating his activities relating to the Jameson Raid, let alone that the s. 70 material was placed there preparatory to the abolition of the section. However, the bureaucratic understanding of the law at this stage upset the abolition applecart, and in August 1897 Chamberlain wrote to Governor Smith to say that his Department had drawn his attention to the requirement of s.33 of the 1842 Act, that Bills be assented to and returned within two years of passing the home colony's legislature and being despatched for assent. The 1894 Bill was now stale, and Chamberlain was returning it, with an invitation to send a fresh, improved Bill. ${ }^{26}$

The understanding of the Colonial Office is of particular interest, as it was obviously felt there that the 1842 Act requirements regarding tabling applied to s.70, even though the content of

${ }^{21}$ WA Hansard vol IX 1896: 1138.

22 BPP vol 34: 501.

${ }^{23}$ BPP vol 34: 516.

${ }^{24}$ WA Hansard, 11 November 1897: 395.

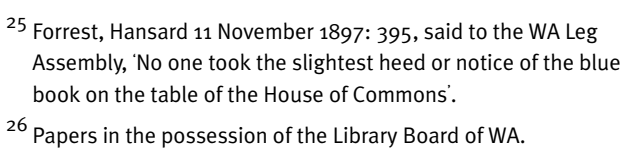

25 Forrest, Hansard 11 November 1897: 395, said to the WA Leg Assembly, 'No one took the slightest heed or notice of the blue book on the table of the House of Commons'.

${ }^{26}$ Papers in the possession of the Library Board of WA. 
s.70 had nothing to do with the substance of the issues spelt out in ss. 31 and 33 of the 1842 Act as requiring reservation if legislated upon. In other words, the effect of s.2 of the 1890 Imperial covering Act (the Western Australian Constitution Act) was adequate to carry over the requirements for reservation from the subjects enumerated in the 1842 Act, to the new subject matter of $1 \%$ for Indigenous welfare set out in s.70. If s. 2 could work that magic for the 1842 Act, could it work also for the 1850 Act?

\section{The second legislative attack}

The colonists duly passed a second Bill for the repeal of s.70 in late 1897, Premier Forrest conceding along the way that 'Of course the Bill would be laid on the table there [the House of Commons] for a certain prescribed time'. ${ }^{27}$ The Bill was duly dispatched to London and received the desired Royal Assent in early 1898, and was returned to WA as the Aborigines Act 1897. The last payment of the $1 \%$ was made in 1897.

Shortly after the Act arrived back in WA, a Mr Thomas Bayley MP asked Chamberlain in the House of Commons what had happened to Chamberlain's suggestion of August 1896 that he lay the correspondence regarding s. 70 before the Commons to obtain the feeling of the House. Chamberlain gave the smuggest of replies: his timing in the tabling had paid off. He pointed out that the correspondence had been laid before the Parliament in February 1897, ' ... and elicited no expression of opinion adverse ... ' to the proposal for the abolition of the Board and s.70. The Bill from the colony had now received the Royal Assent, and that was the end of the matter. ${ }^{28}$

There the story might have finished, but in 1905 an interfering busybody, a meddler, in short just the sort of agitator that Wilde may have had in mind in the passage that ended up in Murphy J's judgement in Neal v The Queen, ${ }^{29}$ named F Lyon Weiss, started asking questions in Perth as to why the other limb of the 1842 Act requirements for reserved Bills, proper proclamation in the Colony, would not also apply to the repeal of s.70. After all, the two year provision had applied, so why not proclamation, and there had been no proper proclamation in the Colony.

The Premier tired of the correspondence from Lyon Weiss, and wrote to London asking for an opinion from the Law Officers of the Crown to settle the argument against the agitator. On 30 October 1905 the Attorney General and the Solicitor General, Finlay and Carson, later to be Lord Chancellor and member of the Law Lords respectively, delivered an opinion that the Aborigines Act 1897 was not 'legally valid as the assent of Her Majesty has not been signified in accordance with the terms of [the 1842 Act] section $33^{\prime} .^{30}$

\section{The third legislative attack}

The WA Parliament set to work immediately to rectify this misfortune, and before the year was out, a new Bill for an Aborigines Act was on its way to London to receive the Royal Assent. This was duly given and the Act returned, complete with the repeal of s.70 and a purported backdating of that repeal to 1897 , to be proclaimed in Perth in early 1906 as the Aborigines Act 1905 .

\footnotetext{
27 WA Hansard, 11 November 1897: 400.

${ }^{28}$ British Hansard, Commons, March 1898: 1496-7.

29 (1982) 149 CLR 305 at 316-17.

30 Reproduced in O'Connell and Riordan 1971: $53 \mathrm{ff}$.
} 


\section{The mystery: was tabling at Westminster required of a s.70 repealing Bill?}

From the records of the Colonial Office we are able to glean what was not a matter of public discussion at the time: dissension as to the function of the 1850 Act requirement for tabling. Some of the lawyers attached to the Colonial Office thought that tabling had been made applicable to all of the small number of matters listed in 5.73 of the WA Constitution, including s.70. If s. 2 of the Imperial covering Act of 1890 worked to make the reservation requirements of the 1842 Act, which of course did not have s.70 in mind, apply to repeal of s.70, then equally the requirements of the 1850 Act, being tabling, should also apply. However, it is apparent that the senior hands in the Colonial Office in both 1897 and 1905, despite Forrest's attempts to demonise them in November 1897 as an unelected force within government, were determined against any requirement of tabling.

The impulse of philanthropy at the heart of Empire, so strong in mid-century, had run its course, and the Home Government now sought only accommodation with the new selfgoverning colonial oligarchies. The tabling of correspondence by Chamberlain in February 1897 was not seen by him as being a constitutional requirement, but merely a courtesy to the House of Commons alone: the material was not tabled in the Lords, as required by s.32 of the 1850 Act.

Nonetheless, the appearance of Imperial might and propriety was preserved, aided by the usual lay confusion over the roles of the various components of Westminster style government. In an essay on Anglican Bishop, and later Archbishop Riley, FJ Boyce wrote that in 1897 ' ... the imperial parliament accepted the ... Bill which provided for the abolition of the Aborigines Protection Board'. ${ }^{31}$

\section{Enter Don McLeod}

Don McLeod worked with Aborigines in the Pilbara from the 1930s, becoming the motive force in the Strelley mob. In the period after the Second World War he organised the Aboriginal station workers into strike action to get proper wages, instead of the baccy and flour that had been the standard to that time. For this McLeod was much hated, and indeed it slowly dawned on me in the years after I first met Don in 1991 that he was the most hated white man in WA. The bitterness lingered on from the moneyed interests, but then nobody wrote a poem for them the way that Dorothy Hewett wrote of Don:

Clancy and Dooley and Don McLeod

Walked by the wurlies when the wind was loud,

And their voice was new as the fresh sap running,

And we keep on fighting and we keep on coming.

Don McLeod beat at a mulga bush,

And a lot of queer things came out in a rush.

Like mongrel dogs with their flattened tail,

They sneaked him off to the Hedland jail. (Etc)

The combination of moneyed interests and State force were determined to take McLeod down, and in August 1946 he was convicted of the offence of being near a Blacks' camp

\footnotetext{
${ }^{31}$ Alexander 1957: 68.
} 
without the permission of a Protector: he was there to show an Anglican clergyman, the Rev Hugh Hodge (also convicted) the way to the camp. The WA Supreme Court showed its usual finesse in dealing with police matters ${ }^{32}$ and the appeal was refused at single judge and Full Court level, before the High Court threw this conviction out $5-0 .{ }^{33}$

McLeod was aware of the Aboriginal complaints at the loss of the $1 \%$, and set about obtaining legal opinions on his chances of overturning the purported repeal of s.70: one from John Toohey when he was a silk, two from Nick Hasluck at different stages of his career, one from Geoffrey Sawer, and another from John Macdonald QC, who had acted for the Banaban Islanders in their fight with the British Government, determined in Tito $v$ Wadell. ${ }^{34}$ All these opinions were of the view that it was too late or too difficult to claim the invalidity of 1905 legislation and sue for the money outstanding, unpaid since 1897.

The memory of s.70 had not dissipated with the years. As Sandy Toussaint wrote, referring to the complaints from Aborigines noted by Paul Seaman in his Aboriginal Land Enquiry Report of 1984, 'Whether or not [John Forrest's] challenge [to s.70] was successful remains a significant and not entirely forgotten point of contention'. ${ }^{35}$

In 1989 Peter Johnston of the UWA Law School, inspired by a short paper read to an administrative law group in Canberra by Toohey J (by then of the High Court), wrote an article in the University of Western Australia Law Review on the story of s.70, ${ }^{36}$ which McLeod read, and was further inspired to the struggle to reinstate s.70. He filed proceedings in the WA Supreme Court in 1993, claiming that the Aborigines Act 1897, and the same named Act of 1905 were invalid for failure to adhere to required manner and form: most importantly neither Bill for these Acts had been tabled at Westminster. The action also sued for the money outstanding, about $\$ 650$ million in 1993 , but as the litigation proceeded, it became apparent that time limitations would prohibit any direct claim to the money, so the suit was pared down to the manner and form point.

\section{The litigation: Judamia $v$ WA}

Snowy Judamia was the eldest of five Elders in the Strelley mob, who had worked with McLeod for many years in mining and pastoral ventures, and who now made themselves the plaintiffs against the State of Western Australia. At an estimated age in his late 90s, Snowy Judamia was of particular use to the plaintiffs' cause because he was born (exact date unknown) prior to 1905 , and it was thought this might be of relevance to the question of standing, although in the long run this proved not to be so.

The Crown (ie the WA Government) moved to strike out Judamia's claim, not by reference to the constitutional issue of manner and form, but by highlighting the inadequacies of the statutory provisions in WA provided for suing the Crown (which at common law may not be sued, so that statutory provisions will be required to allow a claim as of right against the government), and by attacking the standing of the plaintiffs. It was said that they did not have sufficient interest or identification with the subject matter of the litigation to make their position more tangibly affected than the general interest of any other member of the community.

\footnotetext{
${ }^{32}$ See eg Trobridge v Hardy (1955) 94 CLR 147 and Webster $v$

34 (No 2) [1977] Ch 106.

Lampard (1993) 177 CLR 598.

33 Hodge v Needle (1947) 49 WALR 11.

35 McGrath 1995: 251-2.

${ }^{36}$ Johnston 1989: 318.
} 
Justice Owen heard the application for strike out in March 1994, and returned the answer in January 1995. The action could not proceed in its present form, although Owen J thought the question of standing should be reserved for argument at a trial if there was one. ${ }^{37}$

The plaintiffs appealed to the Full Court which delivered a 3-0 affirmation of the strike out on 1 March 1996. ${ }^{38}$ The Court (Malcolm CJ, Rowland and Franklyn JJ) found the Crown Suits Act 1947 to be inadequate to the task of allowing the now appellants' case to proceed.

The appellants took the matter to the High Court, which overruled the State court judgements and determined ex tempore 6-0 (Toohey J having absented himself after having written the advice for McLeod many years earlier) after a two-day hearing concluding on 9 October 1996, that the matter should be struck back in and go to trial.

\section{Yougarla $v$ WA}

Snowy Judamia died before the matter could get to trial, so the next Elder in age, Crow Yougarla, became the leading plaintiff, and the trial extended over three days in May 1998 under the name Yougarla $v$ WA. Justice Murray brought down a judgement in quick time, and the decision in July $1998^{39}$ went against the plaintiffs on the crucial procedural points of standing and the working of the Crown Suits Act. In addition, the plaintiffs lost the argument over the operation of an amendment made to the Interpretation Act in 1994, which purported to make the Australia Acts 1986 (Cth and UK) work backwards in time, so that the abolition of any reservation requirements in the Australia Acts was said to embrace the position in 1897 and 1905. Where the WA Constitution at that time had plainly required reservation for the repeal of s.70 (the fight being over the content of that reservation requirement), the Parliament now claimed to have armed a Tardis with power to change the constitutional scenery in the remote past. There was no reservation requirement at all.

However, the plaintiffs did receive a morale boosting result on the major constitutional point: Murray J found ${ }^{40}$ that the reservation procedure as it existed in 1897 and 1905 required tabling of the Bills to repeal s.70. For this win, senior counsel for Yougarla, David Bennett QC deserves acclamation. It was to the plaintiffs' great disadvantage that Bennett shortly afterwards became Solicitor General of the Commonwealth, and had to leave the case, in which he had been involved from the proceedings in front of Owen J.

The Full Court (Ipp, Anderson and White JJ) had no trouble despatching the appeal, heard in August 1999, and delivered on 11 November 1999. ${ }^{41}$ All three judges agreed that Murray J had been wrong to require tabling for the 1905 Act, although only Anderson J went out of his way to find that there had been no requirements associated with any of the reservations at all, ie, that the Colonial Office lawyers had been wrong in 1897, the Law Officers of the calibre of Finlay and Carson had been wrong in 1905, and there had been no need for the 1905 Act.

The decision of the Full Court is of particular relevance to Aboriginal litigation for the future because of the finding 3-0 that the appellants did not have standing, despite the fact that the High Court decision in Bateman's Bay, ${ }^{42}$ decided one month after Murray J's trial judgement, raised serious issues as to the broadening of standing in constitutional cases. ${ }^{43}$ Bateman's Bay

\footnotetext{
37 WA S Ct Lib No 950137, 23 January 1995.

${ }^{38}$ WA S Ct Lib No 960114.

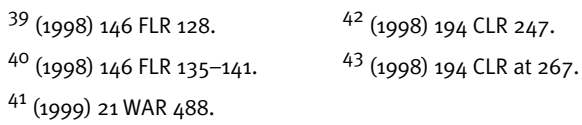


was cited to the Full Court at length, along with an English Court of Appeal decision $R v$ Secretary of State for Foreign and Commonwealth Affairs ex $p$ World Development Movement ${ }^{44}$ to the same effect, but the only indication of that fact was the appearance in the list of authorities in argument, not cited in the judgements, of Bateman's Bay, while the English case did not even get that acknowledgement.

Justice Anderson's approach in particular seems, in the light of the standing decisions coming out of the High Court and senior English courts since the mid-1990s, to be extraordinarily rigid, or just perverse. His theme was that since the appellants had put on no evidence to prove that they had suffered financial loss as the result of the repeal of s.70 (he noted that there had been ongoing funding for Aboriginal welfare of some sort since 1897), they had no tangible interest in the fate of s.70:

In my opinion, the appellants have not demonstrated that they have any interest in the subject matter other than the concern that every right-thinking citizen might have about an alleged episode of unconstitutional conduct on the part of government that has passed into history. No doubt, the concern of the appellants is more strongly felt because they are Aborigines. In my opinion, however, it is clear in point of law that that is insufficient to give them standing to bring this action..$^{45}$

Certainly, at the special leave application to the High Court in August 2000, Gummow and Kirby JJ behaved like gun-dogs sighting the first startled quail when standing was mentioned. The keen interest displayed all came to nought, as in February 2001 Gummow J presided over a directions hearing at which he severed the case, so that the appellants would have to win their manner and form point before the other Crown defences, including standing, would be surveyed by the Court.

The High Court hearing duly took place in March 2001, and the decision was delivered 7-0 against the appellants on 9 August $2001 .{ }^{46}$ Six members of the Court (Gleeson CJ, Gaudron, McHugh, Gummow, Hayne and Callinan JJ) joined in a joint judgement to the effect that the 1842 Act reservation requirements operated in respect of s.70, but by a process of subtle statutory interpretation involving provisos, the wording of s.32 of the 1850 Act did not apply. It followed that the 1905 Act was valid and it worked to backdate the repeal of s.70 to 1897 .

Justice Kirby alone fell for the Anderson J line that the subject matters referred to in the 1842 and 1850 Acts reservation requirements did not look at all like s.70, so they did not affect its repeal. That approach leaves unanswered what work was to be done by the references in the 1890 Imperial covering Act back to 1842 and 1850.

There is a mordant irony in a Court which did not exist when s.70 was enacted in 1890, sitting on its fate in 2001, particularly as the needle threaded by the majority six Justices on provisos (not argued by either party to the argument in the manner adopted by the six) may be rebutted by reference to a Privy Council advice in 1973, itself reversing a Barwick CJ High Court decision in Commissioner of Stamp Duties (NSW) v Atwill. ${ }^{47}$ Atwill had not seemed relevant to the manner in which the two sides' arguments were prepared in writing prior to the hearing, and it was not cited to the Court, which then evolved an argument of its own. I had

\footnotetext{
44 [1995] 1 WLR $386 . \quad \quad 46$ (2001) 207 CLR 344.

45 (1999) 21 WAR 510, [81]. $\quad 47$ [1973] AC 558 at $561 \mathrm{G}$ to $563 \mathrm{D}$
} 
not thought to see the day when I would want appeals to the Privy Council from Australia to be reinstated.

The Court had cited to it a case from the Tudor period, Villers $v$ Beamont ${ }^{48}$ in which Dyer J (as he then was) held that legislation dealing with the rights of widows to property ought to be construed in their favour, as women had no representation in Parliament. Where there was legislative uncertainty as to meaning, it seemed that the same principle should apply in respect of the then disenfranchised Indigenous people of WA, but the Court did not advert to this point.

It remains only to note that the history employed by the Court (not being material argued) was at best unfortunate: the majority referred to the pre-1850 uses of tabling of colonial legislation, ${ }^{49}$ leaving the impression that tabling was an old hat idea before the turn of the nineteenth to the twentieth century, when in fact the NSW Parliament introduced it into the NSW Constitution of 1902. Tabling was the requirement for certain constitutional changes. ${ }^{50}$

In the course of argument, Gummow and Gaudron JJ even tried to introduce the idea of tabling as advantageous to the powerful commercial classes in the colonies, citing the example of WC Wentworth. ${ }^{51}$ This shows no realisation of the course of nineteenth century philanthropy, and the pressure exerted by Aboriginal Protection Societies and their like in London: the WA Parliamentary debates of the 1890s are littered with the colonists' fear and loathing of the 'Exeter Hall faction'. ${ }^{52}$ But Kirby J bought exactly this 'historical' justification, ${ }^{53}$ asserting that the settlers would have been more likely to have had access to the members of the Imperial Parliament than the Aboriginal people of WA. If this were true, slavery would have continued untrammelled throughout the nineteenth century, rather than being the subject of British Parliamentary abolition throughout the first third of that century.

Justice Kirby alone quoted any of the voluminous historical materials cited to the Court. $\mathrm{He}$ set out some of the letter of 28 May 1888 from Broome to Knutsford, referred to above, ${ }^{54}$ but even though he was quoting from the very page, Kirby J did not notice the plain intention on Broome's part that the $1 \%$ be protected against tampering, by the reservation of any amending Bill. ${ }^{55}$ In the end Kirby J's historical analysis amounts to no more than hand wringing over the unhappy fate of an historically meritorious idea: the acceptance that settlers had better access to the Imperial Parliament was followed by the vapid conclusion that we can now never know if tabling would have made any difference or not. ${ }^{56}$ Needless to say, from the point of statutory interpretation and constitutional review, such speculation is utterly devoid of meaning.

What is singularly lacking in either of the High Court judgements, conspicuously so in the joint effort, is any sense of real moral purpose, which immediately informs the knowledgeable reader that choices are being taken which will need to be dressed in the clothes of strict

\footnotetext{
48 (1557) 3 Dyer 146; 73 ER 319.

49 (2001) 207 CLR at 357-358 [28].

${ }^{50}$ See Dixon J in AG (NSW) v Trethowan (1932) 44 CLR 394 at 432.

${ }^{51}$ Austlii transcript of 27 March 2001, p20 of 60.

${ }^{52}$ See text and footnote at $\mathrm{fn} 18$, and text at fn 20 above.

53 (2001) 207 CLR 389 [130].

54 (2001) 207 CLR 381-382 [105]. See text after fn 14 above.

55 The concern expressed by Broome to entrench the $1 \%$ clause may be found at BPP vol 31: 382 , para 24, the reference to alteration in the manner stated in clause 57 of the Bill being to the forerunner of 5.73 ,
}

the section in the 1890 Constitution which would provide for reservation of Bills on some topics to the British Government. Clause 57 of the 1888 Bill specifically referred (vol 31 BPP: 395) to tabling at Westminster, which requirement ceased to exist in express terms in the 1890 Constitution. The High Court avoided the large amount of documentary material that revealed that between 1897 and 1905 very divided views existed in Whitehall between senior government lawyers and functionaries as to whether tabling of the 1897 and 1905 WA Bills for the repeal of 5.70 required tabling at Westminster.

56 (2001) 207 CLR 389 [130]. 
legalism, creating the illusion that there were no choices at all. Contemplate Murphy J in Neal ${ }^{57}$ on the basis of Aboriginal grievance: the quote from the NSW Aboriginal Progress Association in 1938 says it all: '.. there are enough of us remaining to expose the humbug of your claim ...'

\section{Conclusion}

The Aboriginal interest in s. 70 was always doomed, as it depended from inception on a bargain between the Imperial and colonial authorities, and when the Imperial Government lost the stomach for the fight, there was only the law left for the Aborigines to turn to. However, in the nature of twentieth-century history, they would always be too late in getting to the possible legal remedies.

And when they sought those remedies they were met, particularly on the part of the WA Supreme Court, with a withering blast of reminders that they were out of time to use the Crown Suits Act remedies against the Crown, that the Parliament could change constitutional facts backwards in time over a century to deny their rights, and in any case they did not have standing. The system was not theirs to use, leaving the question, of course: if not five Elders from the Pilbara, then who would have standing to sue over an allegedly invalid repeal of a statutory provision in favour of Indigenous people?

I began this paper with Conrad having his character Marlow musing on the idea that might be the redemption for the wresting of the Earth away from the Indigenous peoples. Although Heart of Darkness is set in the Congo, I wonder how much of Conrad's reading of Western Australian atrocity stories in The Times in the 1890s ('Magistrate flogs two blacks to death' is my personal favourite) affected his poised view of the inevitable horrors of colonisation and expropriation.

And what was that idea (so brutally overthrown by the realisation of Kurtz)? The Court door having been slammed on the Indigenous interest in what was meant to be their recompense for land loss, recapturing that idea seems to me to be important for WA. In Can these Bones Live?, Veronica Brady observes that:

Ultimately, if there is no criteria of right and wrong beyond that of human reason, then interest is the key and social power the ultimate arbiter as Hobbes argues and as colonial practice illustrates..$^{58}$

Brady then cites others to come to the conclusion that the argument must be 'that every human being, regardless of race, class or gender is essentially valuable'. To me this still seems to be in the realm of human reason, but it is also emotionally affecting, and goes a long way to my subliminal notions of Conrad's 'idea' as having been to do with a sense of proportion in human affairs.

My problem at this juncture is that I cannot see a treaty bringing about that end in Australia at the present. I fear that the First Nations of this land will have to make and stake out the claim for their own dignity, unassisted by State authority, and only when that is achieved may a treaty serve to celebrate what will be obvious to all but the hardest of hearts (and which should have been obvious all along), that we all share this community together as equal participants and members.

\footnotetext{
57149 CLR at 317-319. $\quad{ }^{58}$ Brady 1996: 134.
} 


\section{References}

\section{Books, articles and official transcripts}

Alexander, F (ed) 1957, Four Bishops and their See, UWA Press.

Australian Legal Information Institute (Austlii) transcript of 27 March 2001.

Brady,V 1996, Can these Bones Live?, Federation Press.

British Parliamentary Papers: Colonies Australia vols 31, 32, and 34, Irish University Press.

Conrad, J 1976, (first published in 1902), Heart of Darkness, Pan Books, London.

Johnston, PW 1989, 'The repeals of section seventy of the Western Australian Constitution Act 1889: Aborigines and Governmental Breach of Trust', UWA Law Review 19: 318.

McGrath, A (ed) 1995, Contested Ground: Australian Aborigines under the British Crown, Allen \& Unwin.

O'Connell, DP and A Riordan 1971, Opinions on Imperial Constitutional Law, Law Book Co, Melbourne.

Papers in the possession of the Library Board of WA.

Pedersen, H 1995, Jandamarra and the Bunuba Resistance, Magabala Books, Broome.

Pullan, R 1984, Guilty Secrets: Free Speech in Australia, Methuen Australia.

Pybus, Cassandra 1991, Community of Thieves, Minerva Australia.

Reynolds, H 1995, Fate of a Free People, Penguin, Melbourne.

— 1998, This Whispering in our Hearts, Allen \& Unwin, St Leonards, NSW.

WA Hansard, vol IX, 1896.

WA Hansard, 11 November 1897.

WA S Ct Lib No 950137, 23 January 1995.

WA S Ct Lib No 960114.

\section{Legislation}

Aborigines Act 1897 (Imp).

Aborigines Act 1905 (WA).

Australia Acts 1986 (Cth and UK).

Australian Colonies Constitution Act (No 1) 1842 (Imp).

Australian Colonies Constitutions Act (No 2) 1850 (Imp).

Crown Suits Act 1947 (WA).

Dawes Act (US) 1887.

Interpretation Act 1994 (WA).

Western Australian Constitution Act 1890 (Imp).

\section{Case law}

AG (NSW) v Trethowan (1932) 44 CLR 394.

Bateman's Bay Local Aboriginal Land Council v The Aboriginal Community Benefit Fund PTY Ltd (1998) 194 CLR 247.

Chagos Islanders v. The Attorney General, Her Majesty's British Indian Ocean Territory Commissioner [2003] EWHC 2222 (QB) QBD.

Cobell v Norton (2001) 240 F 3d 1081 (USCA, 8th Circt). Commissioner of Stamp Duties (NSW) v Atwill [1973] AC 558.

Hodge v Needle (1947) 49 WALR 11.

Neal v The Queen (1982) 149 CLR 305 at 316-17.

$R$ (Bancoult) v Secretary of State for Foreign and Commonwealth Affairs [2001] QB 1067.

$R v$ Secretary of State for Foreign and Commonwealth Affairs ex $p$ World Development Movement [1995] 1 WLR 386.

Tito v Wadell (No 2) [1977] Ch 106, 1977 Chancery Reports 156.

Trobridge v Hardy (1955) 94 CLR 147.

Villers v Beamont (1557) 3 Dyer 146; 73 ER 319.

Webster v Lampard (1993) 177 CLR 598.

Yougarla v WA (1998)146 FLR 128.

Yougarla v WA (1999) 21 WAR 488.

Yougarla v WA (2001) 207 CLR 344. 